\title{
頡顔面領域の血管性病変に対する血管造影術と塞栓療法の検討
}

\author{
松本光治郎 $* * * *$ ・橋 本 温*.宝 田 学* \\ 山田雅文 ${ }^{* *} \cdot$ 最上 博** ・谷岡博昭*
}

\section{Angiography and embolization for vascular lesions in oral and maxillofacial regions}

\author{
Kohjiroh Matsumoto*,*** • Yutaka Hashimoto*. Manabu Takarada* \\ Masafumi YAMAdA** - Hiroshi Mogami** . Hiroaki TANiokA*
}

\begin{abstract}
During the last 8 years between 1983 and 1991, we experienced 46 cases of vascular lesions of the oral and maxillofacial region at the Department of Oral and Maxillofacial Surgery, Ehime University Hospital. Thirty-six cases, which were easily diagnosed as capillary or cavernous hemangioma from clinical findings, were treated by vaporization or excisional surgery by $\mathrm{CO}_{2}$ laser without digital subtraction angiography (DSA) and intravenous radionuclide arteriography (IRA).

The remaining 10 cases were examined by DSA, 8 of these cases also underwent IRA. In DSA, as compared with the conventional film screeen methods, stress was less and resolution of the vascular system higher. Hemodynamics were assessed in detail by IRA. Therefore, diagnostic accuracy was improved. Five cases were treated by transcatheter arterial embolization (TAE) after examination by DSA and/or IRA. Treatment was successful in every case without severe complications. DSA, IRA and TAE were evaluated to be useful and safe for the management of oral and maxillofacial vascular lesions.
\end{abstract}

Key words: digital subtraction angiography (DSA), intravenous radionuclide arteriography (IRA), transcatheter arterial embolization (TAE), vascular lesions in oral and maxillofacial regions (顎颜面領域血管性为変)

緒

\section{言}

顎顔面領域の血管性病変は，ごく小さな血管腫から比

*愛媛大学医学部歯科口腔外科学講座

（主任：谷岡博昭教授）

Department of Oral and Maxillofacial Surgery, Ehime University School of Medicine (Chief:

Prof. Hiroaki Tanioka)

** 愛媛大学医学部放射線科学講座

(主任：浜本 研教授)

Department of Radiology, Ehime University

School of Medicine (Chief: Prof. Ken

Hamamoto)

*** 陸上自衛隊松山駐屯地医務室歯科

Department of Dentistry, Camp Matsuyama, Japan Ground Self-Defense Force 受付日：平成 4 年 3 月 19 日
較的大きな血管腫, さらに動静脈奇形のような広範囲に 及ぶものにまで分類され咀緭, 抜歯, あるいは生検など の際に，致命的な出血をまねくことがある1). したがっ てこれらの病変は的確な診断の下に, 適切な治療を行わ なければならない1，治療には梱包療法，外科療法，薬 物注入療法, 腐蝕法, 電気括よびレーザー焼灼術, 放射 線療法, 冷凍外科療法扣よびそれらの各種併用療法など が行われてきたが，症例によっては必ずしも満足すべき 結果は得られず，その治療法はいまだ確立されていない のが現状である ${ }^{2)}$. 一方, 最近では超選択的血管造影が 可能となり, 塞栓材料, カテーテル, 手技の発達も相ま って血管性病変に対する検査法および治療法が，めざま しい発展を遂げつつある ${ }^{3)}$. 当科でも1983年から顎顔面 領域の 血管性病変の検查法として digital subtraction angiography (以下 DSA), intravenous radionuclide arteriography (以下 IRA), 治療法として transcatheter arterial embolization (以下 TAE) を導入実施してい 
表 1 対象，診断および治療法

\begin{tabular}{|c|c|}
\hline & 症例数 \\
\hline 総 数 & 46 \\
\hline 性別（男性/女性） & $16 / 30$ \\
\hline 年: 龄 & $0.3 \sim 76$ 歳 (平均 37.7 歳) \\
\hline 診 断 & \\
\hline 動静脈奇形 (AVM) & 5 \\
\hline 海綿状血管腫 & 8 \\
\hline 毛細血管腫 & 31 \\
\hline 静脈性血管腫 & 1 \\
\hline リンパ管腫 & 1 \\
\hline \multicolumn{2}{|l|}{ 治療法 } \\
\hline \multicolumn{2}{|l|}{ 外科手術 } \\
\hline 切除術 & 15 \\
\hline 焼灼術 & 14 \\
\hline 冷凍外科療法 & 7 \\
\hline 塞栓術 & 5 \\
\hline 経過観察 & 5 \\
\hline
\end{tabular}

る. 本研究は, 治療成績の改善を目的として当科に扣け る血管性病変の臨床統計的観察と新しい検查法および治 療法としての DSA，IRA 执よび TAE の有用性を評価 検討した。

\section{対象および方法}

対象は，1983年から1991年までの約 8 年間に当科に入 院した顎顔面領域の血管性病変患者46症例であり，年秢 は，生後 4 か月から76歳までであり，平均は37.7歳，性 別は男性16例，女性30例であった，以上を診断，および 治療法について検討し（表 1)，さらにその 46 症例中 DSA を施行した10例については，診断別にIRA, TAE, 外科的手術の実施状況，括よび予後などについて検討し た（表 2,3 ).

\section{結果}

診断の内訳は, 動静脈奇形 5 例, 海綿状血管腫 8 例, 毛細血管腫31例，静脈性血管腫 1 例，リンパ管腫 1 例て あった（表 1 ）。治療法は，切除術 15 例，レーザー焼灼 術14例，冷凍外科療法 7 例，塞栓術 5 例，拈よび幼少な ぞの理由による経過観察 5 例であった（表 1 ).

以上の 46 症例中血管の走行を精査する必要のある10例 について DSA を施行した。 内訳は動静脈奇形 5 例, 海 綿状血管腫 2 例, 毛細血管腫 2 例, リンパ管腫 1 例であ った。この10例中 8 例に IRA を施行し,さらに栄養血 管が特定され塞栓術適応と診断された動静脈奇形 4 例,
表 2 診断別の検查法, 処置法の症例数

\begin{tabular}{l|r|r|r|r|c}
\hline \multicolumn{5}{c}{ 症 例 数 } \\
\hline & DSA & IRA & TAE & $\begin{array}{c}\text { 外科 } \\
\text { 手術 }\end{array}$ & $\begin{array}{c}\text { 経過 } \\
\text { 観察 }\end{array}$ \\
\hline 動静脈奇形(AVM) & 5 & 4 & 4 & 0 & 1 \\
海綿状血管腫 & 2 & 1 & 1 & 1 & 0 \\
毛細血管腫 & 2 & 2 & 0 & 1 & 1 \\
リンハ管腫 & 1 & 1 & 0 & 1 & 0 \\
\hline
\end{tabular}

海綿状血管腫 1 例に TAE を施行した（表 2 ）.

TAE は原則的に 局麻下にて施行した．術後合併症と しては疼痛 4 例，浮腫 2 例および発熱 2 例がみられた以 外は特に重篤な合併症はみられず，消炎鎮痛剤で対処で きた。これら10症例中, 動静脈奇形, 海綿状血管腫, 毛 細血管腫の各 1 例を提示する.

症例

\section{症例 1}

患 者：44歳 男性.

初 診: 1984年5月日日.

主 訴: 右煩部腫脹.

既往歴：1979年頃，交通事故による頭部と顎下部に外 傷.

現病歴：1980年頃，剃毛時に右煩部の腫脹に気付いた が無痛のため放置. その後しばしば摂食時や会話時に， 右下顎臼後部の腫脹を自覚するようになった。ささらに 1984年 1 月頃より右頓部打よび下顎角部に拍動性で弾性 軟の腫脹を認めるようになったため，近医の紹介により 同年 5 月ロ日当科を受診した.

全身所見：右下顎曰後部雬肉からの慢性的出血によ る，軽度の貧血が認められた。

顔貌所見：右煩部および右下顎角部に, それぞれ直径 $50 \times 50 \mathrm{~mm}$ の腫脹および発赤を認めた。

口腔内所見 : 右下顎第 2 小曰歯煩側歯肉部の発赤と, 境界明膫な米粒大の腫脹および漏出性出血があった。 ま た，右臼歯部から左前歯部にかけての口底部に拍動性腫 脹を認めた。

$\mathbf{X}$ 線所見：初診時のパノラマX線写真では, 右下顎骨 臼歯部に多房性の透過像を示した（写真 $1 \mathbf{a}$ ). 右外頸 動脈 DSA では, 右顔面動脈（写真 1b) と右顎動脈 （写真 1 c) の拡張および蛇行を認めた。 また dynamic IRA では ${ }^{99 \mathrm{~m} T c}$ は静注直後に右下顎部に高度集積し, 14秒以内に早期消失したことから血管性病変部の血流が 異常に速いことが示唆された（写真 $1 \mathbf{d}$ ）.

診 断 : 動静脈奇形.

処 置: 1985年 6 月日日, 顔面動脈と顎動脈の永久塞 
表 3 当科における DSA，IRA 抌よび TAE を施行した10症例の一覧。症例 $1 ， 2 ， 3$ は，供覧症例である。

\begin{tabular}{|c|c|c|c|c|c|c|c|c|}
\hline 症例 & 診 断 & $\begin{array}{l}\text { 年齢 } \\
\text { 性別 }\end{array}$ & 部 位 & 臨休症状 & DSA & IRA & 治 療 & 経 \\
\hline 1 & AVM & $\begin{array}{l}\text { 44歳 } \\
\text { 男性 }\end{array}$ & $\begin{array}{l}\text { 右煩部 } \\
\text { 下顎角部 }\end{array}$ & $\begin{array}{l}\text { 拍動性弾性軟の } \\
\text { 腫脹と出血 }\end{array}$ & $\begin{array}{l}\text { 右顎動脈 } \\
\text { 右顔而動脈 }\end{array}$ & $\begin{array}{l}\text { 静注直後に } \\
\text { 高度集積 } \\
\rightarrow \text { 早期消失 }\end{array}$ & TAE & $\begin{array}{l}\text { 軽快したが } 5 \text { 年後に再 } \\
\text { 出血 } \\
\text { 再度塞栓術施行 } \rightarrow \text { 軽快 }\end{array}$ \\
\hline 2 & $\begin{array}{l}\text { 海綿状 } \\
\text { 血管腫 }\end{array}$ & $\begin{array}{l}32 \text { 歳 } \\
\text { 女性 }\end{array}$ & 左煩部 & $\begin{array}{l}\text { 腫脹 } \\
(30 \times 35 \mathrm{~mm}) \\
\text { 鈍痛 }\end{array}$ & $\begin{array}{l}\text { 栄養動脈特 } \\
\text { 定できず } \rightarrow \\
\text { 塞栓不適応 }\end{array}$ & $\begin{array}{l}\text { 晚搏集積 } \\
\rightarrow \text { 持続傾向 }\end{array}$ & $\begin{array}{l}\text { 冷凁外科 } \\
\text { 療法 }\end{array}$ & $\begin{array}{l}\text { 腫脹, おょび鈍痛の消 } \\
\text { 退 } \rightarrow \text { 軽快 }\end{array}$ \\
\hline 3 & $\begin{array}{l}\text { 毛細 } \\
\text { 血管腫 }\end{array}$ & $\begin{array}{l}5 \text { 歳 } \\
\text { 女性 }\end{array}$ & 左煩部 & $20 \times 30 \mathrm{~mm}$ の腫瘤 & $\begin{array}{l}\text { 栄養動脈特 } \\
\text { 定できずー } \\
\text { 塞栓不適応 }\end{array}$ & $\begin{array}{l}\text { 早期集積 } \\
\rightarrow \text { 持続傾问 }\end{array}$ & $\begin{array}{l}\text { 冷谏外科 } \\
\text { 療法 }\end{array}$ & 軽快 $\rightarrow$ 経過観察中 \\
\hline 4 & AVM & $\begin{array}{l}2 \text { 歳 } \\
\text { 女性 }\end{array}$ & $\begin{array}{l}\text { 左上口唇 } \\
\text { 部 }\end{array}$ & $\begin{array}{l}\text { 広範囲な腫脹 } \\
\text { 出血 }\end{array}$ & $\begin{array}{l}\text { 右顎動脈 } \\
\text { 右顔润動脈 }\end{array}$ & & TAE & $\begin{array}{l}\text { 色調の低下, 腫脹の減 } \\
\text { 少 } \rightarrow 2 \text { 作半後脳内出血 } \\
\text { により死亡 }\end{array}$ \\
\hline 5 & AVM & $\begin{array}{l}37 \text { 藏 } \\
\text { 男性 }\end{array}$ & 下顎部 & $50 \times 50 \mathrm{~mm}$ の腫瘤 & $\begin{array}{l}\text { 右顎動脈 } \\
\text { 右顔泊動脈 } \\
\text { 左椎骨動脈 }\end{array}$ & $\begin{array}{l}\text { 静注直後に } \\
\text { 高度集積 } \\
\rightarrow \text { 早期消失 }\end{array}$ & $\begin{array}{l}\text { TAE } \\
\text { (左側は } \\
\text { 行わず) }\end{array}$ & $\begin{array}{l}2 \text { 年 } 4 \text { か月後に再出血 } \\
\text { 再度塞栓術施行 } \\
\text { 現在軽快 }\end{array}$ \\
\hline 6 & AVM & $\begin{array}{l}\text { 13歳 } \\
\text { 男性 }\end{array}$ & 左下茵肉 & $\begin{array}{l}\text { 腫脹 } \\
(25 \times 35 \mathrm{~mm}) \\
\text { 出血 }\end{array}$ & $\begin{array}{l}\text { 左顎動脈 } \\
\text { 左顔听動脈 }\end{array}$ & $\begin{array}{l}\text { 青注注後に } \\
\text { 高度集積 } \\
\rightarrow \text { 早期消失 }\end{array}$ & TAE & $\begin{array}{l}\text { 色調の低下, 腫脤の減 } \\
\text { 少 } \rightarrow \text { 軽快 }\end{array}$ \\
\hline 7 & AVM & $\begin{array}{l}40 \text { 歳 } \\
\text { 男性 }\end{array}$ & 右煩部 & $\begin{array}{l}\text { 腫脹 } \\
(30 \times 30 \mathrm{~mm})\end{array}$ & $\begin{array}{l}\text { 右顎動脈 } \\
\text { 右顔面動脈 }\end{array}$ & $\begin{array}{l}\text { 静注百後に } \\
\text { 高度集積 } \\
\rightarrow \text { 早期消失 }\end{array}$ & & $\begin{array}{l}\text { 適応となる治療法なく } \\
\text { 重篤な臨床症状に乏し } \\
\text { いため経過観察中 }\end{array}$ \\
\hline 8 & $\begin{array}{l}\text { 海綿状 } \\
\text { 血管腫 }\end{array}$ & $\begin{array}{l}54 \text { 歳 } \\
\text { 男性 }\end{array}$ & $\begin{array}{l}\text { 右上齒肉 } \\
\text { 部 } \\
\text { 右煩部 }\end{array}$ & $\begin{array}{l}\text { 約 } 10 \times 10 \mathrm{~mm} \text { の鮮 } \\
\text { 紅色の拍動性腫瘤 } \\
\text { 出血 }\end{array}$ & $\begin{array}{l}\text { 右顔䤉動脈 } \\
\text { 右顎動脈 }\end{array}$ & & TAE & $\begin{array}{l}\text { 周囲組織との色調, 硬 } \\
\text { さに扣いて差異は認め } \\
\text { られないて治癒 } \\
\text { (5年後経過観察) }\end{array}$ \\
\hline 9 & $\begin{array}{l}\text { 毛 細 } \\
\text { 血管腫 }\end{array}$ & $\begin{array}{l}5 \text { 歳 } \\
\text { 女性 }\end{array}$ & $\begin{array}{l}\text { 右煩部 } \\
\text { 右口角部 }\end{array}$ & $\begin{array}{l}\text { 腫脹 } \\
(15 \times 20 \mathrm{~mm})\end{array}$ & $\begin{array}{l}\text { 栄養動脈特 } \\
\text { 定できず } \rightarrow \\
\text { 塞栓不適応 }\end{array}$ & $\begin{array}{l}\text { 早期集積 } \\
\rightarrow \text { 持続傾向 }\end{array}$ & - & $\begin{array}{l}\text { レーザー焼灼術を予定 } \\
\text { しているが，幼少のた } \\
\text { め現在経過観察中 }\end{array}$ \\
\hline 10 & $\begin{array}{l}\text { 舌リン } \\
\text { パ管腫 }\end{array}$ & $\begin{array}{l}7 \text { 歳 } \\
\text { 女性 }\end{array}$ & 舌 & $\begin{array}{l}\text { 舌尖部小腫溜 } \\
(15 \times 10 \mathrm{~mm}) \\
\text { 舌肥大 }\end{array}$ & $\begin{array}{l}\text { 舌リンパ管 } \\
\text { 腫 } \rightarrow \text { 塞栓術 } \\
\text { 不適応 }\end{array}$ & $\begin{array}{l}\text { 異常所見 } \\
\text { なし }\end{array}$ & $\begin{array}{l}\text { レーザー } \\
\text { 切除術 }\end{array}$ & 軽快 $\rightarrow$ 経過観察中 \\
\hline
\end{tabular}

栓を目的として polyvinyl alcohol sponge (以下 PAS) と 金属コイルにて TAE を施行した. 塞栓後 DSA では, 2 つの動脈とも完全に永久塞栓されていた（写真 $1 \mathbf{e}$ ). 右頓部, 下顎角部病変部の拍動は完全に消失した。術後 24時間目に一時閉塞部位の疼痛を訴えたが，同部は壊死 とならず 1 週間後に退院した.

経 過：塞栓後約 5 年間腫脹，拍動および出血を認め なかったが，1989年12月日日夜から右下顎臼歯部の歯肉
出血が翌日昼まで間歇的につづき, 意識低下のため緊急 入院となった. 止血処置と輸血 $1,200 \mathrm{~g}$ にて対処した. 同年12月21日の右外頸動脈の DSA にて顎動脈の再開通 が確認されたため再度 TAE を施行し，1990年 2 月曰日 軽快退院した。1992年 1 月現在異常は認められず経過観 察中である.

\section{症例 2}

患 者: 32歳 女性. 

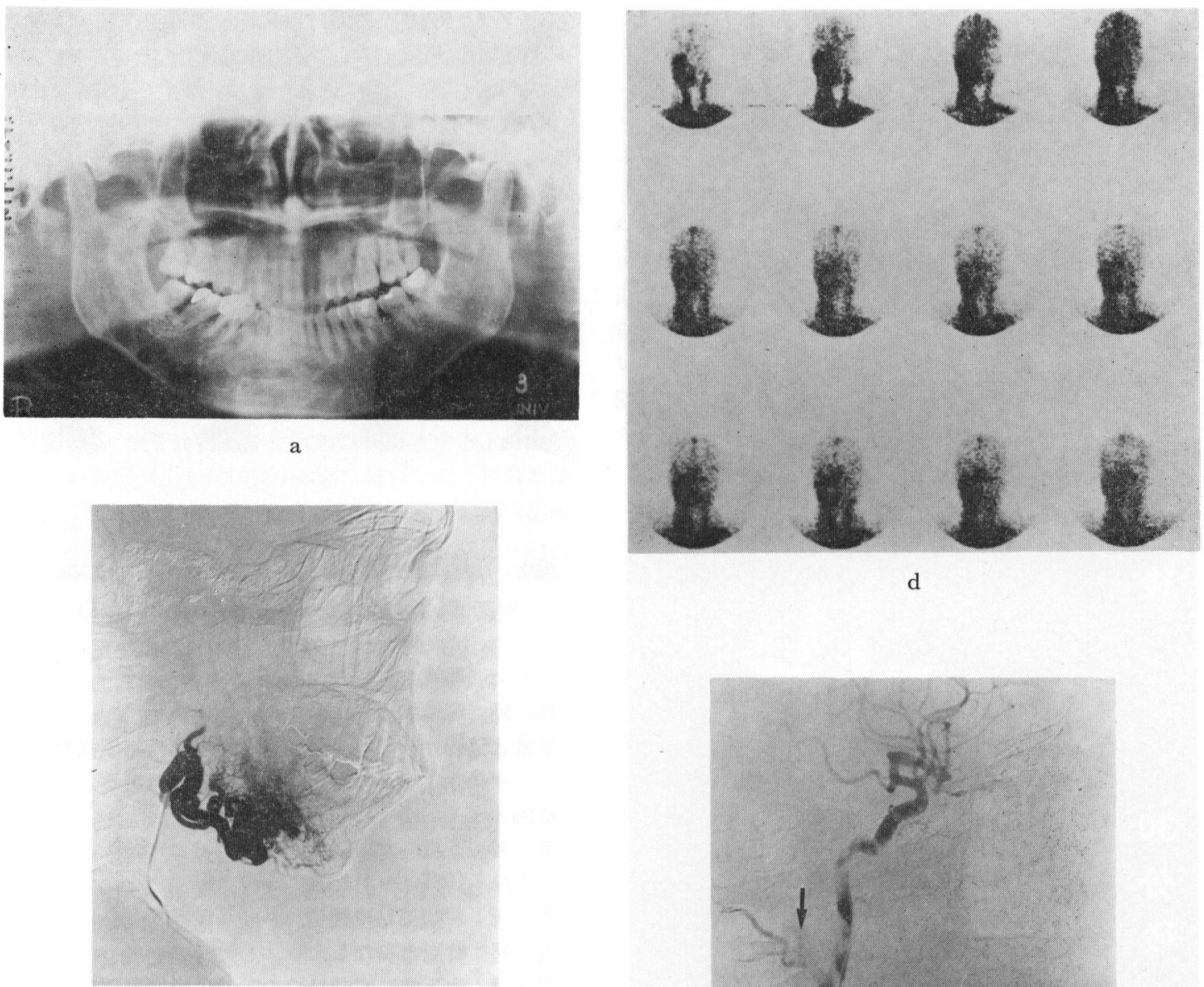

b
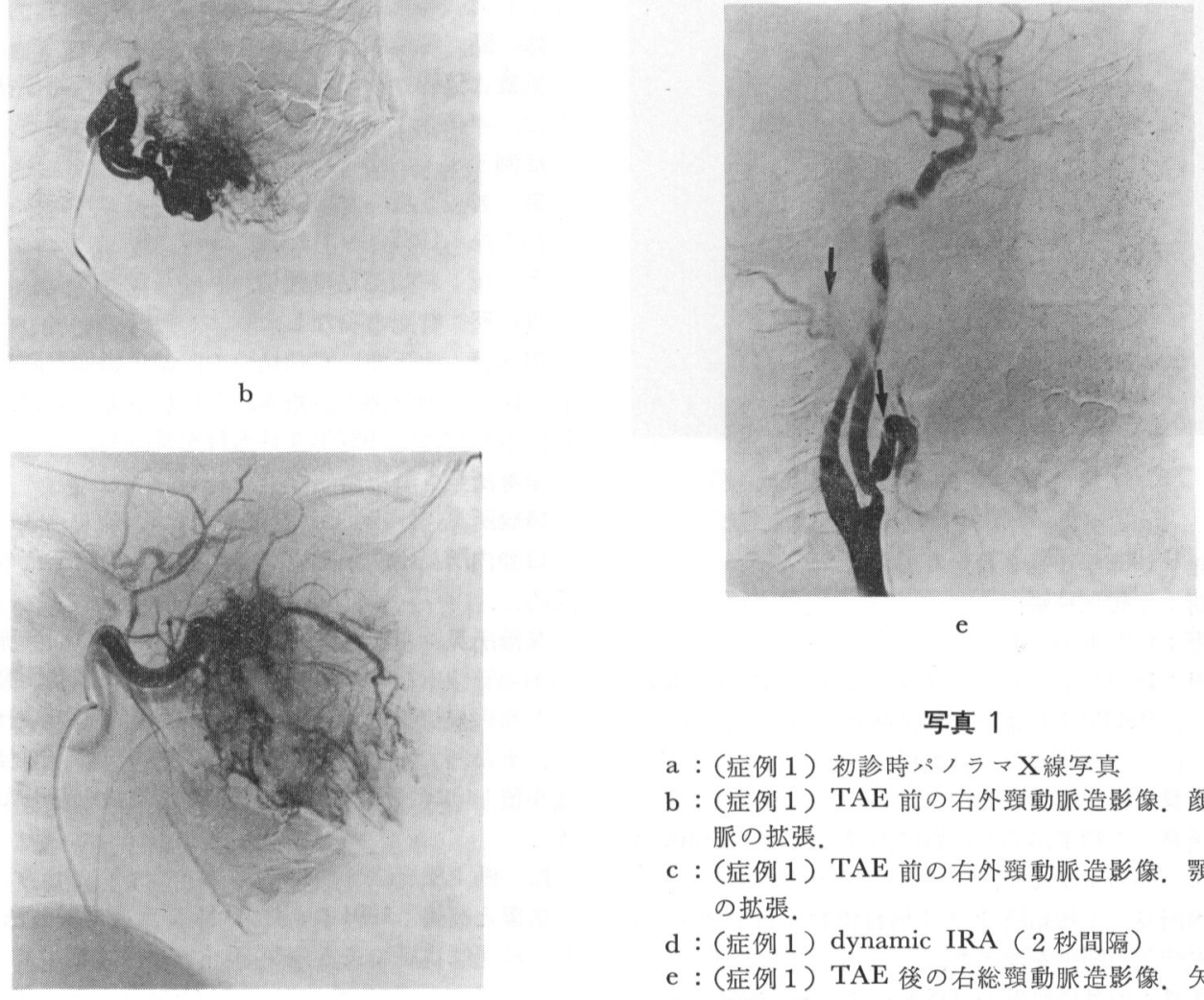

写真 1

a : (症例 1) 初診時パノラマ $\mathrm{X}$ 線写真

b : (症例 1) TAE 前の右外澒動脈造影像. 顔面動 脈の拡張。

c : (症例 1) TAE 前の右外頸動脈造影像，顎動脈 の拡張

$\mathrm{d}$ : (症例 1 ) dynamic IRA ( 2 秒間隔)

$\mathrm{e}$ : (症例 1 ) TAE 後の右総頸動脈造影像. 矢印は 金属コイルを示す。 


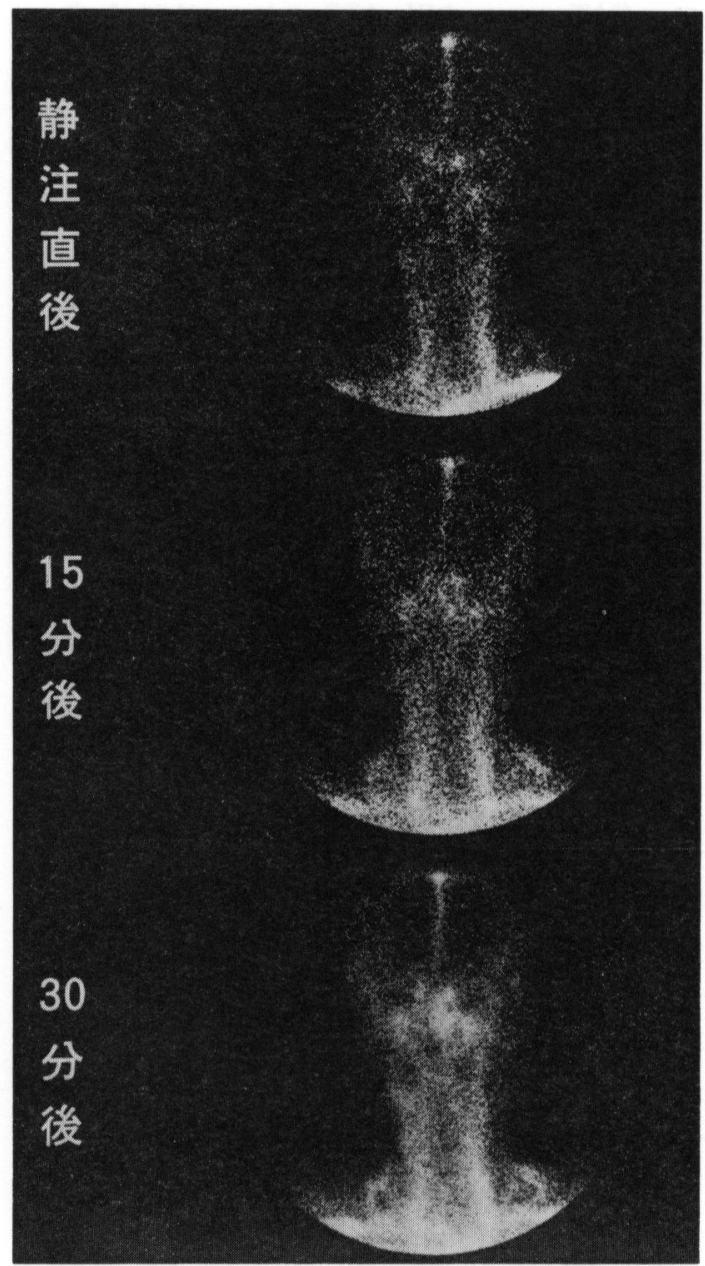

写真 2 症例 2 : static IRA

初 診: 1986年 6 月曰日.

主 訴: 左煩部腫脹.

既往歴：特記事項なし。

現病歴：1978年頃より, 左煩部执よび左頓粘膜に腫脹 を認めた。1986年 5 月より，同部腫脹の増大と鈍痛を認 め，紹介により同年 6 月曰日当科を受診した。

全身所見：特記事項なし。

顔貌所見：左頓部から左口唇にかけて，30×35mm の 腫脹特よび発赤を認めた。

口腔内所見：左頓粘膜より上唇粘膜にかけて $20 \times 25$ $\mathrm{mm}$ の赤紫色の腫脹を認めた。

X線所見：左外頸動脈の DSA では左顔面動脈末梢に 血管腫と思われる濃染像を認めたが，左顔面動脈を含め 周囲の動脈の拡張および蛇行などの所見は認められなか った. static IRA では, ${ }^{99 \mathrm{~m}} \mathrm{Tc}$ は静注直後の早期相で は集積は認められず，15３0分後の晚期相で徐々に集積

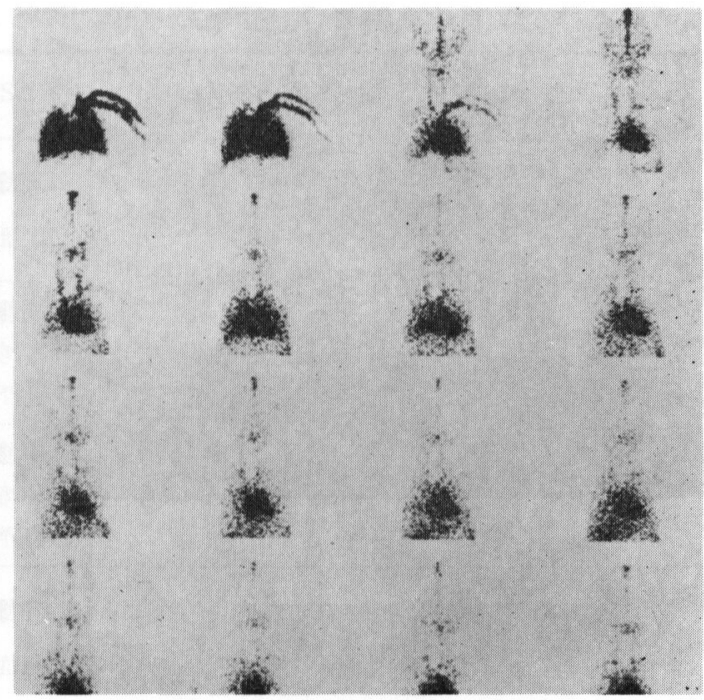

写真 3 症例 3 : dynamic IRA（2 秒間隔）

を示した（写真 2).

診 断 : 海綿状血管腫.

処置と経過：1986年 7 月日日に, 冷凍外科療法を施行 した。術後 5 年半たったが，経過は良好である。

症例 3

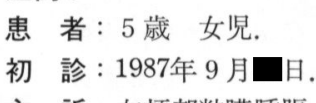

主 訴: 左煩部粘膜腫脹.

既往歴：特記事項なし。

現病歴：生下時に左頓粘膜の暗紫色膨瘤を認め, 某総 合病院にて血管腫と診断されたが放置していた。 その後 近医の紹介にて1987年 9 月当科を受診した.

全身所見：特記事項なし.

顔貌所見：同上.

口腔内所見：左煩粘膜に $20 \times 30 \mathrm{~mm}$ の暗紫色の腫瘤を 認めた。

X線所見：左外頸動脈の DSA では左顔面動脈末梢に 毛細血管腫を思わせる濃染像を認めたが, 顔面動脈を含 めた周囲の拡張叔よび蛇行などの所見は認められなかっ た。また dynamic IRA では, ${ }^{99} \mathrm{~m} T \mathrm{c}$ は静注 6 秒後に高 度集積し 32 秒経過後も比較的強い集積を示した（写真 3 ).

診 断 : 毛細血管腫.

処置と経過：1991年 8 月 日に冷凍外科療法を施行 し，経過は良好である。

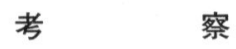

1. DSA について

当科に招いて過去 8 年間で入院を要した血管性病変患 
者46例中, 今回呈示した10例に DSA を施行した. いわ ゆる血管造影は, 生検や試験穿刺に比較して出血の危険 性がなく手技が比較的簡単であり, 病変の診断とその大 きさ，範囲を推定する上で，重要な情報資料となる4). 今回施行した DSA は造影剂の注入量, 注入速度が従来 のフイルム・スクリーン法に比較してはるかに少ないた め, より径の小さいカテーテルを用いることが可能で, 外来で動脈造影を行らこともできるようになった．最近 出現した高分解能 DSA 装置によって画像的にもフィル ムによる血管造影とほとんど遜色ない段階に達してい る5).

\section{IRA について}

IRA は，血管性病変の 血流動態を診査する上で有効 と考え, 今回呈示した10例中 8 例に施行した. 従来の血 管造影では得ることのできない血管性病変の血流の状況 の判断に有効であり, その病態により特徵的なパターン が認められた。すなわち塩入ら ${ }^{6)}$ の報告のように血流䡃 態から推定して毛細血管腫では静注直後から患部に比較 的強い集積が出現し持続傾问を示すのに対し, 動静脈奇 形では静注直後に高度集積が出現し早期に消失する。ま た海綿状血管腫では早期集積は認めず，30分以降の晚期 像で集積が出現すると考えられた。 したがって IRAを 施行した 8 症例では症例 $1,5 ， 6 ， 7$ は動静脈奇形, 症例 2 は海綿状血管腫, 症例 3,9 は毛細管血管腫之誩 断された（表了）。なお症例10は dynamic image, static image ともに異常所見は認められず，舌生検より舌リン パ管腫と診断された。

\section{TAE について}

1) 栓子の決定

栓子として報告されている材質は多数あるが，代表的 なものとしてはゼルフォーム, シリコン小球, PAS, 金 属コイル，メチルメタクリート，筋肉片などである ${ }^{1)}$. 塞栓後の手術を前提とする場合もしくは塞栓の効果を一 時的に知りたい場合にはゼルフォームを使用するが，永 久的な塞栓を期待する場合には用いない、いずれの栓子 を用いるにしても，目的は機械的塞栓によりその部位で の血栓形成を促進し，血流を遮断することにあるので症 例に応じ最適の栓子を選択することが重要である6,7).

著者らの症例では, Seldinger 法により先ず外頸動脈 DSA を施行し，病巣部への栄養動脈を確認し可能な限 りカテーテルを進め, PAS (径 $200 \mu$ ) あるいはゼルフ オーム紐片（約 $1 \times 1 \mathrm{~mm}$ 大）扰よび金属コイルを用い て, TAE を施行した。

\section{2 ) 外科的結禁の限界について}

顎顔面領域の動静脈奇形の栄養血管は, 従来考えられ たよりはるかに複雑な血管の関与が示されてきており， 外頸動脈の各枝のみならず内頸動脈，椎骨動脈の枝扣よ び反対側外頸動脈の吻合枝などが関与する場合もある. このことは従来の動静脈奇形の治療法としての外頸動脈
結禁が，過去に扣いて多くの症例で結果的に無効であっ たことの原因と考えられる6,9,13). さらに応急処置とし ての外頸動脈結禁がやむを得ず行われたとしても，その ために血流動態に変化を与え, さらに複雑な側副血行路 の拡大を招く危険性が考慮されなければならない,13).

著者らの経験した症例 5 （表 3）の場合も, 初診より10 年前に左外頸動脈結禁の既往があり, その後たびたび出 血をくり返していた症例であり, 左外頸動脈結紮が結果 的には左側の TAE を不可能にし, 血流動態の変化扣よ び側副血行路の拡大化に関与した可能性は否定できな い. このように複雑な血管の関与は従来の外科的結紫の 限界を示唆するものであり, 超選択的に 塞栓する TAE の有効性は，この点にもあると考兄られる.

3 ）合併症および禁忌

外頸動脈領域の TAE では超選択的塞栓術がなされな い限り, 外頸動脈之内頸動脈の吻合がある場合や外頸 動脈と椎骨動脈の吻合がある場合は，TAE は禁忌とな $ろ^{3,9)}$. 術前に完全な血管造影を行い血管系解剖を詳細 に検査する必要がある。また術中に最も注意すべきこ とは, 塞栓子の内頸動脈への逆流および閉塞である.

Manelfe は27例中 5 例之高率に内頸動脈への栓子の迷入 を認め, 塞栓後これを確かめる意味で内頸動脈造影をす ることをすすめている ${ }^{3,8)}$. 著者らも症例 1 において内 頸動脈に一部塞栓物質 (PAS) が閉塞し, 頸部より外科 的に総頸動脈を露出切開し摘出した合併症を経験した. また期待されらる塞栓効果が得られない場合は塞栓術を 中止すべきである。栓子が静脈側へ通過し, 肺塞栓の起 こる可能性も考虑する必要がある ${ }^{3,10 \sim 12)}$. 術後の合併症 として患部周囲の正常組織の潰瘍形成, 疼痛, 浮腫括よ び発熱などがある。著者らの症例では疼痛 4 例, 浮腫 2 例扣よび発熱 2 例がみられた以外に特に重篤な合併症は みられず，消炎鎮痛剂で対処できた。

4) TAE と外科的切除術の関連について

TAE を単独での根治療法とするのか, または外科的 切除術の補助療法とするのかの選択は, 病態によると考 える. Djinjian らは TAE の適応として, 外科的切除の 範囲を越えるか致命的大出血の予想される巨大病変, あ るいはハイリスクなどのため外科手術の禁忌である場合 をあげて扣り，その適応の拡大を強調している ${ }^{10,13,14)}$. 著者らの症例では, 結果的には 5 例とも塞栓術の単独療 法であったが，その中で症例 6 , 症例 8 の 2 例は術後の 切除手術を前提として TAEを施行した。 しかし， 2 例 とも結果がきわめて良好であり，切除術による外科的侵 襲を望まない患者扣よび家族の希望を考慮して手術は行 わなかった。一方, 症例 1 と症例 5 は巨大病変であり, 症例 4 はハイリスクのため外科的手術禁忌であると判断 して塞栓術の単独療法を施行した.

顎顔面領域の血管性病変に対する TAE の適応や長期 間にわたる予後に関しては今後の問題点と思われるが， 
著者らの経験した症例では，有効かつ比較的安全な治療 法と考兄られた。

$$
\text { 結 語 }
$$

1. 顎顔面領域の血管性病変46例中10例飞対し DSA,

IRA を施行し, その内 5 例に TAEを施行した.

2. 全症例に重篤な合併症はなく, 診断精度の向上拉 よび臨床症状の改善がみられた。

3. 外頸動脈領域の血管性病変飞対する DSA, IRA 招 よび TAE は比較的安全で有効な検查拈上び治療法であ り積極的に応用していくべきであると考兄られた。

\section{引 用 文 献}

1) Hashimoto, Y., Matsuhiro, K., et al.: Therapeutic embolization for vascular lesions of the head and neck. Int $\mathrm{J}$ Oral Maxillofac Surg 18: 47-49 1989.

2）橋本賢二, 塩田重利, 他: 最近の10年間に挏け る血管腫の臨床統計的観察. 日口外誌 23: 6806881977.

3）高橋伸明，菊地晴彦，他：脳外科疾患飞括汗る 経大腿カテーテル塞栓 術。脳外 11: 591-602 1983.

4) 田村 稔, 桜井精人, 他: Catheter embolization を応用した下顎骨中心性血管腫の 1 治驗 例。 口科誌 33: 474-485 1984 .

5）八代直文：血管造影の変遷. 医学のあゆみ 139:
495-497 1986.

6) 塩入重彰, 大西正俊, 他：カテーテル栓塞法の 顎骨血管腫治療への応用。日口外誌 27: 7487561981.

7) Longacre, J.J., Benton, C., et al.: Treatment of facial hemangioma by intravascular embolization with silicone spheres. Plast Reconstr Surg 50: 618-621 1972.

8）佐:竹幸雄, 田代英雄, 他: 下顎骨中心性血管腫 の 1 例。 日口外誌 21：170-175 1975.

9）山田雅文, 最上: 博, 他: 動脈塞栓術を施行し た口腔外科領域の血管腫。臨放 34：967-971 1989.

10) Djindjian, R., Cophignon, J., et al.: Embolization by superselective arteriography from the femoral route in neuroradiology: review of 60 cases: I technique, indications, complications, Neuroradiology. 6: 20-26 1973.

11) Manelfe, C., Espango, J., et al.: Therapeutic embolization of cranio-cerebral tumors. J Neuroradiol 2: 257-274 1975.

12) Bentoson, J., Rand, R., et al.: Unexpected complications following therapeutic embolization. Neurosurgery 16: 420-423 1978.

13）坂下英明, 東野純也, 他：下顎骨に発生した 動静脈奇形の 1 例。 日外誌 $32: 2336-2353$ 1986.

14) Djindjian, R.: Indications, contraindications and complications in embolization of the external carotid artery. J Neuroradiol 2: 173-200 1975. 